\title{
Seroprevalence of hepatitis B virus among antenatal clinic attendees in Gamawa Local Government Area, Bauchi State, Nigeria
}

\author{
Garba Umar Mustapha ${ }^{1,2,3^{*}}$ (D, Abdulrasul Ibrahim ${ }^{4}$, Muhammad Shakir Balogun', \\ Chukwuma David Umeokonkwo ${ }^{1,5}$ and Aisha Indo Mamman ${ }^{6}$
}

\begin{abstract}
Background: Hepatitis B virus disease is a potentially life-threatening liver infection and a major global health problem. It causes chronic infection and puts people at high risk of death from cirrhosis and liver cancer. WHO estimated 257 million people are living with hepatitis B virus (HBV) infection and in 2015 alone HBV resulted in to 887,000 deaths globally. We determined the prevalence and associated factors of hepatitis B virus infection among Antenatal Care (ANC) attendees in Gamawa Local Government Area, Bauchi State.

Methods: We conducted a descriptive cross-sectional, health facility-based study between March and April 2018. We used systematic random sampling technique to recruit 210 pregnant women aged 15-49 years. With a structured questionnaire, we interviewed the respondents and collected blood sample to test for hepatitis B surface antigen. We calculated frequencies, means, proportions, and tested for associations using Epi Info 7.2 and Microsoft Excel.

Results: The mean age of respondents was $24.5 \pm 6.0$ years; 112 (53\%) of whom were younger than 25 years. All were married, 183 (87\%) had no formal education and up to 190 (90\%) were employed. Overall, 14 (6.7\%) tested positive for HBsAg; women aged $\geq 35$ years had the highest prevalence (10\%). None with tertiary education tested positive and women married before 18 years had 13 (6.2\%) prevalence.

Conclusions: The prevalence of HBsAg among pregnant women in Gamawa LGA was 6.7\% which is quite lower than the national prevalence reported. We recommended improved surveillance of HBV infection and screening of women attending ANC.
\end{abstract}

Keywords: Hepatitis B virus, Hepatitis B surface antigen, Prevalence, Pregnancy, Health facilities, Hepatitis B

\section{Background}

Hepatitis B virus disease is a potentially life-threatening liver infection and a major global health problem. Hepatitis B infection is associated with the risk of death arising from cirrhosis, liver and non-liver cancers [1]. Transmission of Hepatitis B virus (HBV) results from exposure to contaminated blood or body fluids, unprotected sexual contact with an infected person, blood transfusion, use of contaminated needles, syringes, and

\footnotetext{
* Correspondence: gmustapha20@gmail.com

'Nigeria Field Epidemiology and Laboratory Training Programme, Abuja, Nigeria

${ }^{2}$ Department of Community Medicine, Ahmadu Bello University, Zaria,

Kaduna State, Nigeria

Full list of author information is available at the end of the article
}

sharps as well as vertical transmission from mother to child. There is risk of HBV transmission to the newborn delivered by a hepatitis B surface antigen (HBsAg)-positive woman. This risk is amplified with positivity of hepatitis B envelope antigen (HBeAg) [2].

Globally, WHO estimates that in 2015, 257 million persons, or $3.5 \%$ of the population, were living with chronic HBV infection. The African and Western Pacific regions accounted for $68 \%$ of those infected. In Nigeria, the National Program on Immunization (NPI) which targets the infants, started in 1998. Hepatitis B vaccine coverage for infants were $50.6 \%$ for first dose, $45.6 \%$ second dose and $38.2 \%$ for third dose [3]. In Bauchi State the vaccination coverage ranges from $25.4 \%$ for first 
dose, $18.9 \%$ second dose and $12.5 \%$ for third dose [3]. The third dose of Pentavalent vaccine coverage among children has increased from $12.5 \%$ in 2013 to $32.1 \%$ in $2018[3,4]$.

Several authors have reported on the prevalence of HBV among sub-populations worldwide with estimates varying depending on population studied and methods used. Reported prevalence of HBsAg among pregnant women varies from one region to another. The prevalence of chronic HBV infection was estimated to be $3.5 \%$ among women of reproductive age globally [5]. In African countries the prevalence ranges within $6-25 \%$ [5]. A national survey of hepatitis B in Nigeria showed prevalence of $12.2 \%$ among the general population [6], a systematic review of hepatitis $\mathrm{B}$ infection among pregnant women in Nigeria found a prevalence of $14.1 \%$ [7]. HBsAg prevalence documented among pregnant women in Bayara, Bauchi State was 17.2\% [8].

Many authors report on the prevalence of HBV among sub-populations in Nigeria in secondary and tertiary healthcare settings and usually in urban areas, with estimates varying depending on population studied and methods used. However, there is dearth of reliable data on prevalence of HBV infection among pregnant mothers at primary health care level especially remote areas. Also, despite Nigeria being categorized among countries where HBV infection is highly endemic [9], Gamawa LGA reported zero case of HBV infection to the state surveillance system for five consecutive years (2011-2015). We therefore aimed to determine the prevalence of $\mathrm{HBV}$ infection among pregnant mothers attending ANC at PHCs of Gamawa LGA.

\section{Methods}

\section{Study design and setting}

We conducted a cross-sectional study among women receiving antenatal care (ANC) in Primary Health Centres (PHCs) of Gamawa LGA, Bauchi State between March and April 2018. Gamawa LGA has an estimated projected population of 427,761 (2018) [10]. It is a rural LGA and farming is the predominant occupation of the people. The LGA has 18 political wards and $62 \mathrm{PHCs}$ out of which 24 offered ANC services. Among the PHCs that offered ANC, the services were offered once weekly in most of the health facilities and average ANC attendance was 30 clients per facility per day.

\section{Sample size determination}

We calculated a sample size of 210 using the formula for cross sectional studies [11] based on the documented HBsAg prevalence of $14.1 \%$ among pregnant women in Nigeria [7] at $95 \%$ confidence interval (CI), 0.05 precision and $10 \%$ non-response rate.

\section{Sampling technique}

We employed multistage sampling method to recruit 210 pregnant women. At the first stage, we recruited eight health facilities (HFs) from the list of $24 \mathrm{HFs}$ that provide ANC using balloting method of simple random sampling. At the second stage, we recruited clients attending ANC in the selected HFs using systematic random sampling. We planned to collect the sample over 8 weeks. Using the average daily attendance to ANC in the selected hospitals, we estimate a sampling interval of 10 . The first attendee is sampled by balloting and subsequently every 10th attendee was approached for the study till the sample size was achieved. After explaining the purpose of the study, written informed consent was obtained, the questionnaire was administered, and one millilitre of blood sample was collected through an aseptic venipuncture for HBV serology.

\section{Study instrument and data collection}

The participants were interviewed by the investigator and research assistants using a semi-structured questionnaire to obtain information on socio-demographic characteristics, history of vaccination, blood transfusion, surgery, tonsillectomy, dental procedure, sharing of needles, and history of cupping, scarification and episiotomy. The questionnaires were both in English and Hausa. After this one millilitre of blood was collected aseptically for hepatitis B serology. We excluded ANC attendees that were not residing in Gamawa LGA.

\section{Laboratory method}

HBsAg was assayed using an enzyme-linked immunosorbent assay (ELISA) kit produced by LabACON ${ }^{\mathrm{R}}$ (Hangzhou Biotest Biotech Co., Ltd., China) which has sensitivity and specificity of 99.9 and $99.0 \%$ respectively. The 99.9 and $99.0 \%$ for sensitivity and specificity are company declared figures which are similar to other commercial figures. The kit has in-built controls. The manufacturer's instruction were closely followed. The results were reported as positive or negative.

\section{Statistical analyses}

Data analysis was performed using Microsoft Excel and Epi-Info 7.2. We estimated the proportion of pregnant women positive to HBsAg, frequency and proportion of the various sociodemographic and clinical characteristics. We examined the relationship between the HBsAg status and the sociodemographic and clinical characteristics using the chi square statistics at the 95\% confidence interval. All the women contacted for the study have agreed and participated in the Study, there were no issues with test method and collection of data. 


\section{Result}

A total of 210 pregnant women were enrolled in the study. The mean age was $24.5 \pm 6.0$ years, median age was 24 years (interquartile range $20-28$ years). All were married, $87 \%$ had no formal education and up to $91 \%$ were employed. Overall, 6.7\% (3.8-10.7\%) tested positive for HBsAg, those older than 35 years had the highest prevalence of $10.5 \%$ (1.8-30.6\%, Table 1). None was positive among those with tertiary education, and women married before 18 years had 6.5\% (3.5-10.7\%) prevalence. There was no statistically significant difference between the proportions of HBsAg positives and negatives with respect to history of vaccination, blood transfusion, surgery, tonsillectomy, dental procedure, sharing of needles, history of cupping, scarification and episiotomy. There was also no statistically significant difference in the proportion of $\mathrm{HBsAg}$ positives and negatives with respect to age, level of education, employment status, husband's occupation, parity, age at the time of first marriage and number of marital units. (Table 2).

\section{Discussion}

HBV infection affecting pregnant women may result in maternal morbidity and mortality. It could also result in chronic infection in the newborn. Prevalence of hepatitis $B$ infection varies in different parts of the world. Even within the same country there are regional and population specific variations. Immunosuppression in pregnancy is of clinical and epidemiological relevance with regards to hepatitis B viral infection [12]. In this study the overall prevalence of HBsAg among women attending antenatal care services in PHCs in Gamawa LGA was $6.7 \%$ indicating an intermediate endemicity. This

Table 1 Socio-demographic characteristics and prevalence of HBsAg among women attending ANC in PHCs of Gamawa LGA, Bauchi State, Nigeria $(N=210)$

\begin{tabular}{|c|c|c|c|c|}
\hline Variable & $\mathrm{HBsAg}+\mathrm{ve}$ & HBsAg-ve & Prevalence (95\% Cl) & Total \\
\hline Overall prevalence & 14 & 196 & $6.7(3.8-10.7)$ & 210 \\
\hline \multicolumn{5}{|l|}{ Age group (years) } \\
\hline $15-24$ & 7 & 105 & $6.3(2.8-12.0)$ & 112 \\
\hline $25-34$ & 5 & 74 & $6.3(2.4-13.5)$ & 79 \\
\hline$\geq 35$ & 2 & 17 & $10.5(1.8-30.6)$ & 19 \\
\hline \multicolumn{5}{|l|}{ Educational Level } \\
\hline No formal/Qur'anic & 11 & 172 & $6.0(3.2-10.2)$ & 183 \\
\hline Primary & 1 & 15 & $6.2(0.3-27.2)$ & 16 \\
\hline Secondary & 2 & 8 & $20.0(3.5-52.0)$ & 10 \\
\hline Tertiary & 0 & 1 & $0.0(0-95)$ & 1 \\
\hline \multicolumn{5}{|l|}{ Occupation } \\
\hline Farmer & 6 & 83 & $6.7(2.8-13.5)$ & 89 \\
\hline Trader & 4 & 57 & $6.6(2.1-15.1)$ & 61 \\
\hline Tailor & 2 & 25 & $7.4(1.3-22.4)$ & 27 \\
\hline Housewife & 1 & 19 & $5.0(0.2-22.3)$ & 20 \\
\hline Others & 1 & 12 & $7.8(0.4-32.5)$ & 13 \\
\hline \multicolumn{5}{|l|}{ Employment Status } \\
\hline Employed & 10 & 163 & $5.8(3.0-10.1)$ & 173 \\
\hline Unemployed & 4 & 47 & $7.8(2.5-17.8)$ & 51 \\
\hline \multicolumn{5}{|l|}{ Parity } \\
\hline Primiparous & 6 & 56 & $9.7(4.0-19.0)$ & 62 \\
\hline Multiparous & 8 & 140 & $5.4(2.5-10.0)$ & 148 \\
\hline \multicolumn{5}{|l|}{ Age at First Marriage } \\
\hline$<18$ & 12 & 174 & $6.5(3.5-10.7)$ & 186 \\
\hline$\geq 18$ & 2 & 22 & $8.3(1.4-24.9)$ & 24 \\
\hline \multicolumn{5}{|c|}{ Number of sexual partners } \\
\hline 1 & 10 & 148 & $6.3(3.3-11.0)$ & 158 \\
\hline$>1$ & 4 & 48 & $7.7(2.5-17.5)$ & 52 \\
\hline
\end{tabular}


Table 2 Factors associated with HBV infection among women attending ANC in PHCs of Gamawa LGA, Bauchi State, Nigeria

$(N=210)$

\begin{tabular}{|c|c|c|c|}
\hline \multirow[t]{2}{*}{ Risk factor } & \multicolumn{2}{|c|}{ Hepatitis B status } & \multirow[t]{2}{*}{ OR $(95 \% \mathrm{Cl})$} \\
\hline & Positive n (\%) & Negatives n (\%) & \\
\hline \multicolumn{4}{|l|}{ Age (Years) } \\
\hline$\leq 30$ & $12(6.5)$ & $174(93.5)$ & \multirow[t]{2}{*}{$0.8(0.16-3.61)$} \\
\hline$>30$ & $2(8.3)$ & $22(91.7)$ & \\
\hline \multicolumn{4}{|l|}{ Education } \\
\hline$\leq$ Primary & $12(6.0)$ & $187(94.0)$ & \multirow[t]{2}{*}{$0.3(0.06-2.17)$} \\
\hline > Primary & $2(18.2)$ & $9(81.8)$ & \\
\hline \multicolumn{4}{|c|}{ Employment Status } \\
\hline Employed & $13(6.7)$ & $181(93.3)$ & \multirow[t]{2}{*}{$1.1(0.13-8.81)$} \\
\hline Unemployed & $1(6.2)$ & $15(93.8)$ & \\
\hline \multicolumn{4}{|l|}{ Parity } \\
\hline Primiparous & $6(9.7)$ & $56(90.3)$ & \multirow[t]{2}{*}{$1.9(0.62-5.65)$} \\
\hline Multiparous & $8(5.4)$ & $140(94.6)$ & \\
\hline \multicolumn{4}{|c|}{ Age at first marriage } \\
\hline$\leq 18$ & $12(6.5)$ & $174(93.5)$ & \multirow[t]{2}{*}{$0.8(0.16-3.61)$} \\
\hline 18 and above & $2(8.3)$ & $22(91.7)$ & \\
\hline \multicolumn{4}{|c|}{ Number of sexual partners } \\
\hline 1 & $10(6.3)$ & $148(93.7)$ & \multirow[t]{2}{*}{$0.8(0.24-2.70)$} \\
\hline$>1$ & $4(7.7)$ & $48(92.3)$ & \\
\hline \multicolumn{4}{|c|}{ History of blood transfusion } \\
\hline Yes & $2(9.5)$ & $19(90.5)$ & \multirow[t]{2}{*}{$1.6(0.32-7.46)$} \\
\hline No & $12(6.3)$ & $177(93.7)$ & \\
\hline \multicolumn{4}{|l|}{ History of surgery } \\
\hline Yes & $1(25.0)$ & $3(75.0)$ & \multirow[t]{2}{*}{$4.9(0.48-50.96)$} \\
\hline No & $13(6.3)$ & $193(93.7)$ & \\
\hline \multicolumn{4}{|c|}{ History of Uvulectomy } \\
\hline Yes & $0(0.0)$ & $18(100.0)$ & \\
\hline No & $14(7.3)$ & $178(92.7)$ & \\
\hline \multicolumn{4}{|c|}{ Local dental procedure } \\
\hline Yes & $0(0.0)$ & $4(100.0)$ & \\
\hline No & $14(6.8)$ & $192(93.2)$ & \\
\hline \multicolumn{4}{|c|}{ Sharing of needles } \\
\hline Yes & $0(0.0)$ & $4(100.0)$ & \\
\hline No & $14(6.8)$ & $192(93.2)$ & \\
\hline \multicolumn{4}{|l|}{ Cupping } \\
\hline Yes & $2(4.1)$ & $47(95.9)$ & \multirow[t]{2}{*}{$0.5(0.11-2.45)$} \\
\hline No & $12(7.5)$ & $149(92.5)$ & \\
\hline \multicolumn{4}{|l|}{ Scarification } \\
\hline Yes & $4(8.5)$ & $43(91.5)$ & $1.4(0.43-4.76)$ \\
\hline No & $10(6.1)$ & $153(93.9)$ & \\
\hline Vaccination & & & \\
\hline Yes & $0(0.0)$ & $9(100.0)$ & \\
\hline No & $14(7.0)$ & $187(93.0)$ & \\
\hline
\end{tabular}

contrasts with reports by Colin et al [9] that classified Nigeria in the high endemicity group. The finding from our study supports the fact that the prevalence of HBV infection varies widely based on location and subpopulations. The implication of this finding is that pregnant women, even in rural communities, are at high risk of $\mathrm{HBV}$ infection, hence the need for HBV screening during antenatal care services. The result from our study is similar to that from a study done by Oluboyo et al [12] and is in agreement with prevalence of $6-25 \%$ in the WHO African region. Suffice to note that similar results by all study groups may be linked to identical WHO approved test kits.

The prevalence is lower than a similar study conducted in Bayara hospital, Bauchi State where a prevalence of $17.2 \%$ was documented [8]. The difference could be due to the fact that it was conducted in secondary facility situated in urban area. A prevalence of $8.2 \%$ was reported also from north eastern Nigeria in FMC Yola, Adamawa State [13]. In the North-Central geopolitical zone, a prevalence of $12.3 \%$ was reported from Minna Niger State by Ndams et al [14] and 11.0\% was reported in Makurdi, Benue State by Mbaawuaga et al. [15]

In the south-western part of the country, a prevalence of $16.5 \%$ was reported in Osogbo, Osun State by Kolawole et al [16] and $8.3 \%$ in Ibadan by Chinenye et al. [17] Southern states reported a prevalence of $12.5 \%$ in Edo State by Ugbebor et al. [18] It is also lower than the 9.6-18.6\% observed by Musa et al [7] in a country wide systematic review. Furthermore, it is lower than the $9.7 \%$ found among pregnant women attending ANC in Bue'a Health District [19], 10.2\% found by Noubiap et al [20], $20.4 \%$ found by Ducancelle [21] et al in Cameroon. It's also lower than the $9.5 \%$ found in Ghana by Ephraim et al [22] and 9.3\% found in Kenya by Okoth et al [23]. The differences in the reported seroprevalence rates of HBV among pregnant women may be due to variation in the geographical location, socio-cultural practices, study design, level of care for the study facility, sample size and test methods employed. Most of the studies quoted above were carried out at secondary and tertiary level of care located mostly in urban or semi urban populations but this study was carried out at primary health care setting in rural communities. The lower prevalence of HBV compared to the previous Nigerian studies may be due to increased awareness about the disease [24].

However, the prevalence from our study is higher than the $4.3 \%$ found among pregnant women in Zaria, northwestern-Nigeria, 5.3\% in Yenagoa, Bayelsa State; 1.6\% found in Iran [25]; 3.9\% found in pregnant women attending ANC in Muhimbili national hospital Tanzania [26] and 5.6\% in Sudan [27]. It was similar to a prevalence of $6.8 \%$ reported in Ekiti State, southwestern 
Nigeria [28], and 6.6\% in Cross River State [29] southsouth Nigeria. The differences may reflect variations in overall health care status of the study locations. The cost of screening could have accounted for lack of surveillance reports from Gamawa. The cost of screening for HBV in the community was $\$ 1.39$ per client. The amount is considered high for the average person in the community due to high level of poverty in the rural community. Since they are apparently healthy, it becomes difficult to convince the women to part with the money that would have rather been used for food. Making these screenings free during antenatal visits would help a lot in ensuring that every woman knows her status and take steps to improve her health and protect her unborn baby. PHC facilities hence do not routinely screened for HBV infection.

\section{Conclusion}

The prevalence of HBsAg among pregnant women in Gamawa LGA was $6.7 \%$ which is much lower than the national prevalence of $14.1 \%$ among ANC attendees. Women older than 35 years had the highest prevalence of $10 \%$ and of the documented associated factors studied, none was found to be associated with HBV infection. We recommended free HBV screening for women attending ANC and more awareness campaigns on hepatitis $B$ virus infection and its consequences especially among pregnant women.

\section{Abbreviations \\ ANC: Ante Natal Care; Cl: Confidence Interval; ELISA: Enzyme Linked Immunosorbent Assay; FMC: Federal Medical Centre; HBeAg: Hepatitis B envelope antigen; HBsAg: Hepatitis B surface antigen; HBV: Hepatitis B Virus; HF: Health Facility; LGA: Local Government Area; NPI: National Programme on Immunization; PHC: Primary Health Centres; WHO: World Health Organisation}

\section{Acknowledgements}

We acknowledged the Nigeria Field Epidemiology and Laboratory Training Programme for supporting the procurement of reagents and other forms of support.

\section{Authors' contributions \\ GMU conceptualized the study, designed it, acquired, analysed and interpreted the data. AIM was the chairman supervisory committee and a major contributor in writing the manuscript. Al co-supervised the project, contributed in writing the manuscript and support the interpretation of the data. MSB revised the manuscript and help in re-writing it. CDU support the analysis and interpretation of data and reviewed the manuscript. All authors read and approved the final manuscript.}

\section{Funding}

There was no funding for the study.

\section{Availability of data and materials}

The datasets used and/or analysed during this study are available from the corresponding author on reasonable request.

\section{Ethics approval and consent to participate}

We obtained ethical approval from Bauchi State Research Ethics (reference\#: MOH/GEN/S/1409/1). Informed written consent was obtained from each pregnant woman who agreed to participate in the study before questionnaire administration and sample collection. All the participants aged $15-<18$ years were legally married and pregnant, so we considered them emancipated minors and did not need parental/guardian consent. They consented for themselves. The ethics committee considers such individuals emancipated being legally married according to the state laws. Participant's identifiers were kept securely, and confidentiality was maintained.

Study participants were notified of their HBsAg status and advised for further action that may be needed. Results were also shared with the eight Health Facilities where the study was conducted, Local Primary Health Care Development Authority and State Ministry of Health for their action.

\section{Consent for publication}

Not Applicable.

\section{Competing interests}

The authors declare that they have no competing interests.

\section{Author details \\ ${ }^{1}$ Nigeria Field Epidemiology and Laboratory Training Programme, Abuja, Nigeria. ${ }^{2}$ Department of Community Medicine, Ahmadu Bello University, Zaria, Kaduna State, Nigeria. ${ }^{3}$ State Primary Health Care Development Agency, Bauchi, Bauchi State, Nigeria. ${ }^{4}$ Department of Medical Microbiology, Ahmadu Bello University Teaching Hospital, Zaria, Kaduna State, Nigeria. ${ }^{5}$ Department of Community Medicine, Alex Ekwueme Federal University Teaching Hospital, Abakaliki, Ebonyi State, Nigeria. ${ }^{6}$ Department of Haematology, Ahmadu Bello University Teaching Hospital, Zaria, Kaduna State, Nigeria.}

Received: 29 May 2019 Accepted: 6 February 2020

Published online: 06 March 2020

\section{References}

1. Song C, LV J, Liu Y, Chen JG, Ge Z, Zhu J, et al. Associations between hepatitis $B$ virus infection and risk of all Cancer types. JAMA Netw Open. 2019;2(6):e195718.

2. Gentile I, Borgia G. Vertical transmission of hepatitis B virus: challenges and solutions. Int J Women's Health. 2014;6(1):605-11.

3. National Population Commission, Abuja, Nigeria. Nigeria demographic and health survey 2013. Abuja: National Population Commission Federal Republic of Nigeria; 2014.

4. National Population Commission, ICF. Nigeria Demographic and Health Survey 2018 Key Indicators Report [Internet]. Abuja; 2019 [cited 2019 Jul 3]. Available from: https://dhsprogram.com/pubs/pdf/PR118/PR118.pdf.

5. Ott JJ, Stevens GA, Groeger J, Wiersma ST. Global epidemiology of hepatitis $B$ virus infection : new estimates of age-specific HBsAg seroprevalence and endemicity. Vaccine. 2012;30(12):2212-9 Elsevier Ltd.

6. Olayinka AT, Oyemakinde A, Balogun MS, Ajudua A, Nguku P, Aderinola M, et al. Seroprevalence of hepatitis B infection in Nigeria: a national survey. Am J Trop Med Hyg. 2016;95(4):902-7.

7. Musa BM, Bussell S, Borodo MM, Samaila AA, Femi OL. Prevalence of hepatitis B virus infection in Nigeria, 2000-2013: a systematic review and meta-analysis. Niger J Clin Pract. 2015;18(2):163-72.

8. Ndako J, Echeonwu G, Nwankiti O, Onovoh E, Ujah A, Ikani P, et al. Hepatitis $B$ virus Sero-prevalence among pregnant females in Nothern Nigeria. Res J Med Sci. 2012;6(3):129-33.

9. Shepard CW, Simard EP, Finelli L, Fiore AE, Bell BP. Hepatitis B virus infection : epidemiology and vaccination. Johns Hopkins Bloom Sch Public Health. 2017;28(October):112-25.

10. National Population Commision, Data for National Development. 2016. https://nigeria.opendataforafrica.org/ifpbxbd/state-population-2006.

11. Kish L. Survey Sampling. New York: Wiley; 1965. p.202.

12. Oluboyo B, Ugochukwu V, Oluboyo A, Ihim A, Chukwuma G, Ogenyi S, et al. Prevalence of hepatitis $B$ and $C$ viral infections in pregnant women attending antenatal clinic in Nnewi, Nigeria. Eur Sci J. 2014;10(3):434-41.

13. Olokoba AB, Salawu FK, Danburam A, Olokoba LB, Midala JK, Badung LH, et al. Hepatitis $B$ virus infection amongst pregnant women in north-eastern Nigeria - a call for action. Niger J Clin Pract. 2011;14(1):10-3.

14. Ndams I, Joshua I, Luka S, Sadiq H. Epidemiology of Hepatitis B infection among pregnant women in Minna, Niger State, Nigeria. Sci World J. 2008;3:5-8. 
15. Mbaawuaga E, Enenebeaku M, Okopi J, Damen J. Hepatitis B virus (HBV) infection among pregnant women in Makurdi, Nigeria. Afr J Biomed Res. 2008;11(11):155-9.

16. Kolawole OM, Wahab AA, Adekanle DA, Sibanda T, Okoh Al. Seroprevalence of hepatitis B surface antigenemia and its effects on hematological parameters in pregnant women in Osogbo, Nigeria. Virol J. 2012;9:2-7.

17. Chinenye G, Adeola F, Chukwuma E, Rasheed A. Prevalence, sociodemographic features and risk factors of hepatitis $B$ virus infection among pregnant women in southwestern Nigeria. Pan Afr Med J. 2015;8688:1-11.

18. Ugbebor O, Aigbirior M, Osazuwa F, Enabudoso E, Zabayo O. The prevalence of hepatitis $B$ and $C$ viral infections among pregnant women. N Am J Med Sci. 2011;3(5):238-41.

19. Besong Frambo AA, Atashili J, Nde Fon P, Martins NP. Prevalence of HBsAg and knowledge about hepatitis B in pregnancy in the Buea Health District, Cameroon: a cross-sectional study. BMC Res Notes. 2014:7:394.

20. Noubiap JJN, Nansseu JRN, Ndoula ST, Bigna JJR, Jingi AM, Fokom-Domgue $J$. Prevalence, infectivity and correlates of hepatitis B virus infection among pregnant women in a rural district of the far north region of Cameroon. BMC Public Health. 2015;15(1):454.

21. Ducancelle A, Abgueguen P, Birguel J, Mansour W, Pivert A, Guillouguillemette $\mathrm{L}$, et al. High Endemicity and low molecular diversity of hepatitis B virus infections in pregnant women in a Rural District of North Cameroon. PLoS One. 2013;8(11):10-2.

22. Ephraim R, Donko I, Sakyi SA, Ampong J, Agbodjakey H. Seroprevalence and risk factors of Hepatitis $B$ and Hepatitis $C$ infections among pregnant women in the Asante Akim North Municipality of the Ashanti region, Ghana; a cross sectional study. Afr Health Sci. 2015;15(3):1-5.

23. Okoth F, Mbuthia J, Gatheru Z, Murila F, Kanyingi F, Mugo F. Seroprevalence of hepatitis B markers in pregnant women in Kenya. East Afr Med J. 2006;83(9):485-93.

24. Locarnini S, Hatzakis A, Chen D, Lok A. Review Strategies to control hepatitis B : Public policy, epidemiology, vaccine and drugs. J Hepatol. 2015;62(1): S76-86 European Association for the Study of the Liver.

25. Afzali $H$, Heravi MM, Moravveji S, Poorrahnama M. Prevalence of hepatitis B surface antigen in pregnant women in Beheshti Hospital of Kashan, Isfahan. Iran Red Crescent Med J. 2015;17(7):22-6.

26. Rashid S, Kilewo C, Aboud S. Hepatitis B Virus Infection Among Antenatal Clinic Attendees At the Muhimbili National Hospital, Seroprevalence and Associated Factors. 2011. Available from: http://hdl.handle.net/123456 789/21.

27. Elsheikh RM, Daak AA, Elsheikh MA, Karsany MS, Adam I. Hepatitis B virus and hepatitis C virus in pregnant Sudanese women. Virol J. 2007;3(4):8-10

28. Esan AJ, Omisakin CT, Owoseni MF, Fasakin KA, Ogunleye AA. Seroprevalence of hepatitis $B$ and hepatitis $C$ Virue co-infection among pregnant women in Nigeria. Am J Biomed Res. 2014;2(1):11-5.

29. Utoo BT. Hepatitis B surface antigenemia (HBsAg) among pregnant women in southern Nigeria. Afr Health Sci. 2013;13(4):1139-43.

\section{Publisher's Note}

Springer Nature remains neutral with regard to jurisdictional claims in published maps and institutional affiliations.

Ready to submit your research? Choose BMC and benefit from:

- fast, convenient online submission

- thorough peer review by experienced researchers in your field

- rapid publication on acceptance

- support for research data, including large and complex data types

- gold Open Access which fosters wider collaboration and increased citations

- maximum visibility for your research: over $100 \mathrm{M}$ website views per year

At $\mathrm{BMC}$, research is always in progress.

Learn more biomedcentral.com/submissions 